\title{
Research
}

\section{Human Activity Differentially Redistributes Large Mammals in the Canadian Rockies National Parks}

\author{
James Kimo Rogala $^{1,2}{ }^{\text {, Mark Hebblewhite }}{ }^{3}$, Jesse Whittington ${ }^{1}$, Cliff A. White ${ }^{1}$, Jenny Coleshill ${ }^{2}$, and
} Marco Musiani ${ }^{2}$

\begin{abstract}
National parks are important for conservation of species such as wolves (Canis lupus) and elk (Cervus canadensis). However, topography, vegetation conditions, and anthropogenic infrastructure within parks may limit available habitat. Human activity on trails and roads may lead to indirect habitat loss, further limiting available habitat. Predators and prey may respond differentially to human activity, potentially disrupting ecological processes. However, research on such impacts to wildlife is incomplete, especially at fine spatial and temporal scales. Our research investigated the relationship between wolf and elk distribution and human activity using fine-scale Global Positioning System (GPS) wildlife telemetry locations and hourly human activity measures on trails and roads in Banff, Kootenay, and Yoho National Parks, Canada. We observed a complex interaction between the distance animals were located from trails and human activity level resulting in species adopting both mutual avoidance and differential response behaviors. In areas $<50 \mathrm{~m}$ from trails human activity led to a mutual avoidance response by both wolves and elk. In areas 50 - 400 m from trails low levels of human activity led to differential responses; wolves avoided these areas, whereas elk appeared to use these areas as a predation refugia. These differential impacts on elk and wolves may have important implications for trophic dynamics. As human activity increased above two people/hour, areas 50 - $400 \mathrm{~m}$ from trails were mutually avoided by both species, resulting in the indirect loss of important montane habitat. If park managers are concerned with human impacts on wolves and elk, or on these species' trophic interactions with other species, they can monitor locations near trails and roads and consider hourly changes of human activity levels in areas important to wildlife.
\end{abstract}

Key Words: Banff National Park; conditional logistic regression; elk; human activity; resource selection; trails; wolves; Yellowstone National Park

\section{INTRODUCTION}

Habitat loss from an increasing and expanding human population is the greatest threat to a wide diversity of species (Wilcove et al. 1998, Brooks et al. 2002). The establishment of parks has been an important strategy to prevent direct habitat loss and to preserve biologically important flora and fauna (Margules and Pressey 2000). However, parks may be susceptible to habitat degradation or indirect habitat loss from both natural and anthropogenic disturbances (Peters and Darling 1985, Baker 1992, Hobbs and Huenneke 1992). For example, many wildlife species in mountainous areas are affected by topographical fragmentation and indirect habitat loss by steep rugged mountain ranges. Additionally, anthropogenic infrastructure and human activity in mountainous landscapes are primarily located on valley bottoms, which often contain the most productive habitat for wildlife species, further increasing fragmentation and limiting available habitat (Gibeau et al. 1996, Paquet et al. 1996).

Recreation and transportation may have an array of immediate and long-term impacts on species within wilderness parks (Boyle and Samson 1985, Forman and Alexander 1998, Trombulak and Frissell 2000). Activities such as hiking and biking on trails, and vehicle activity on roads may affect a wide range of species such as moose (Alces alces; Yost and Wright 2001), mule deer (Odocoileus hemionus; Freddy et al. 1986), bobcats (Lynx rufus) and coyotes (Canis 
latrans; George and Crooks 2006), bighorn sheep (Ovis canadensis; Keller and Bender 2007), bison (Bison bison) and pronghorn (Antilocapra americana; Taylor and Knight 2003), small mammals (Oxley et al. 1974), Brown-headed Cowbirds (Molothrus ater), bald eagles (Haliaeetus leucocephalus; Buehler et al. 1991, Miller et al. 1998), and black bears (Ursus americanus; Kasworm and Manley 1990). For many of these species, wildlife use near human activity decreased substantially, often leading to indirect habitat loss. For example, avoidance of human activity by woodland caribou (Rangifer tarandus caribou) on seismic exploration lines and roads resulted in loss of up to $48 \%$ of habitat in Alberta, Canada (Dyer et al. 2001). However, in other systems, wildlife species differentially responded to human activity according to trophic level. For example, in Grand Teton National Park, Berger (2007) found that grizzly bear avoidance of human activity because of presumed higher risk of mortality (e.g., Nielsen et al. 2004), created a refugia for female moose and their calves. This suggests a cascading top-down trophic interaction hypothesis whereby carnivores but not their prey avoided human activity, resulting in a refugia for prey. These indirect human effects on trophic dynamics could lead to human mediated trophic cascades on plant communities and species dependent upon those plants (e.g., Hebblewhite et al. 2005). Understanding how increasing human activity affects the intensity and extent of habitat use by different trophic levels has important implications for land managers and for indirect habitat loss mitigation strategies.

Indirect habitat loss caused by avoidance of trails and roads has been documented for wolves (Canis lupus; Theuerkauf et al. 2003, Whittington et al. 2004, Hebblewhite and Merrill 2008), consistent with this species treating human disturbance as predation risk, perhaps because of higher mortality near humans despite protection (Hebblewhite et al. 2003). For elk (Cervus canadensis), however, responses were more variable; where some authors reported avoidance (Cassirer et al. 1992, Gagnon et al. 2007), others reported selection for areas near human activity (Hebblewhite et al. 2005), suggesting that both avoidance and trophic interaction may occur in different populations. However, most previous research on the effects of human activities on wolf and elk selection has occurred at relatively coarse spatial-temporal scales. For example, previous research that has used human activity models at broad spatial scales includes Theuerkauf et al. (2001), Anderson et al. (2005), and Shively et al. (2005). Research using human activity models at broad temporal scales, i.e., summer vs. winter, includes Jedrzejewski et al. (2001) and Sawyer et al. (2007). Other research has compared human activity levels between circadian cycles, i.e., day vs. night (Schultz and Bailey 1978, Ciucci et al. 1997, Ager et al. 2003, Theuerkauf et al. 2003) or between different activity-level trails/ roads, i.e., high vs. low activity (Rost and Bailey 1979, Thurber et al. 1994, Ager et al. 2003). These analyses assume a constant response across spatiotemporal scales, and may obscure the true relationship between humans and wildlife. Human activity levels vary both spatially and temporally. For example, if a species response to human activity is measured at the temporal scale of day vs. night across the entire study area, there may be locations within the study where the daytime human activity level, i.e., a low activity road, equals the nighttime level, i.e. a high-activity road. In this case, research may incorrectly assume that these two roads incur similar responses by wildlife during the day or night. To identify fine-scale wildlife responses to human activity levels, researchers would ideally use temporally varying human activity levels spatially across many different trails and roads. Such an approach would allow researchers to understand whether wildlife were able to distinguish changes in human activity levels at finer spatio-temporal scales, i.e., within the circadian cycle at individual trails and roads. As a result, managers could potentially mitigate the negative effects of human activity by managing the timing and amount of human activity.

Our research investigates the relationship between modeled fine-scale (hourly) human activity levels on roads and trails and the distribution of wolves and elk near these linear features. Specifically, we tested the effects of modeled hourly human activity on wolf and elk use of areas adjacent to trails and roads across three mountainous national parks of the Canadian Rockies. We tested the hypothesis that humans had an equal effect on both species, vs. the trophic interaction hypothesis of Berger et al. (2001), whereby wolves but not elk would avoid human activity, thus providing elk with a 'human' shield. We test these hypotheses using GPS radio telemetry from 32 individuals of the two species in a paired-logistic resource selection function framework (Compton et al. 2002). Finally, we tested for thresholds in the response of wildlife to human activity levels. Our study is among the first to 
Fig. 1. Location of study area: Banff, Kootenay, and Yoho National Parks within the provinces of British Columbia and Alberta, Canada.

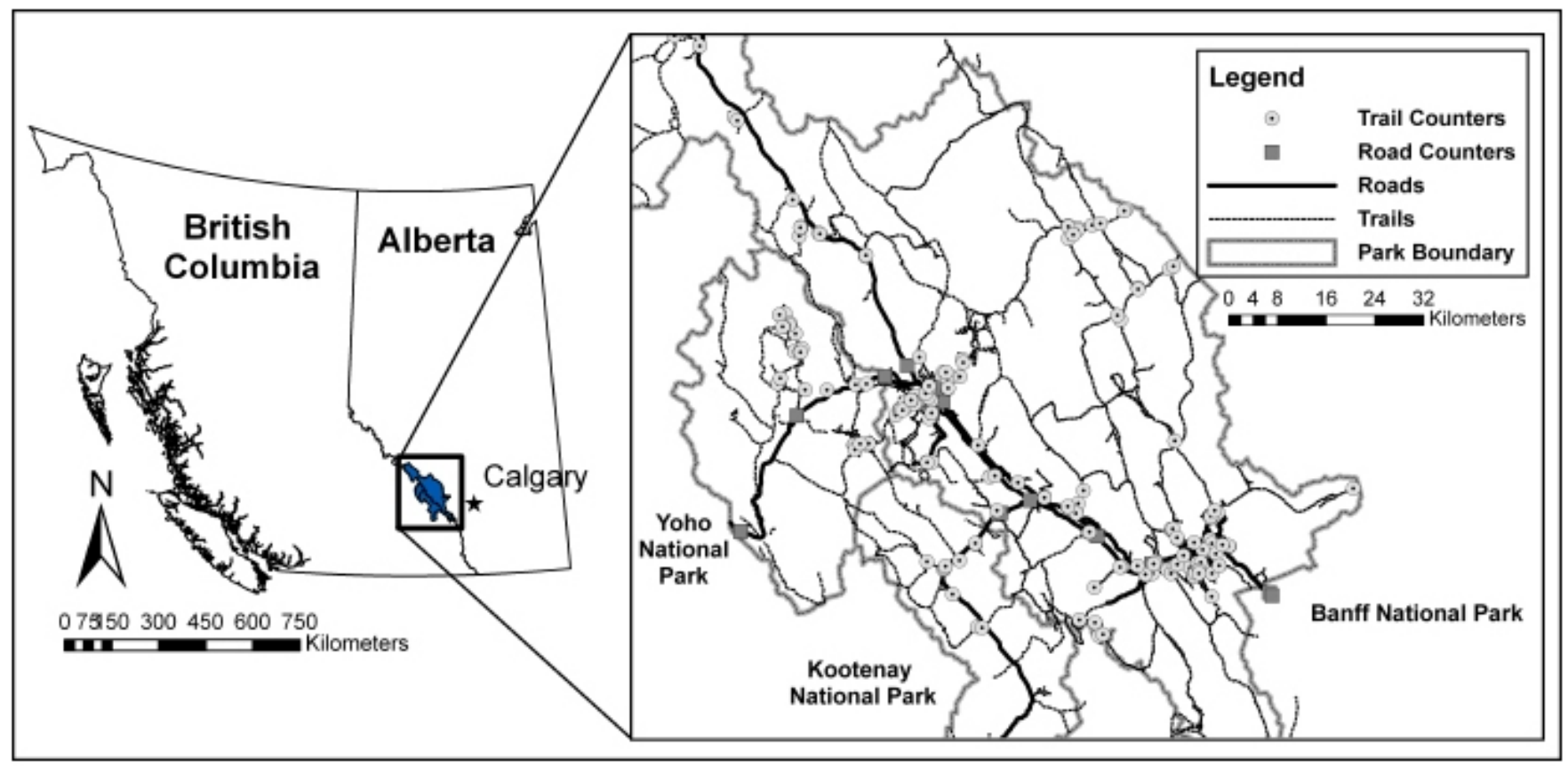

combine GPS collars with hourly human activity data to test for fine-scale wildlife-human interactions.

\section{METHODS}

\section{Study area}

Banff, Kootenay, and Yoho National Parks are located in the Canadian Rocky Mountains approximately $150 \mathrm{~km}$ west of Calgary (Fig. 1). They are adjacent parks covering $9360 \mathrm{~km}^{2}$ in southwestern Alberta and southeastern British Columbia. The topography of the area is mountainous with rugged slopes, steep-sided ravines, and flat valley bottoms. Ecoregions include montane, subalpine, and alpine, which correspond to increasing elevation and decreasing productivity (Holland and Coen 1983). Vegetation in the area includes lodgepole pine (Pinus contorta), white spruce (Picea glauca), Engelmann spruce (Picea engelmannii), subalpine fir (Abies lasiocarpa), poplar (Populus sp.), and Douglas fir (Pseudotsuga menziesii; Holroyd and Van Tighem 1983). In addition to our research species, wildlife in the area includes black bear, grizzly bear (Ursus arctos), cougar (Puma concolor), lynx (Felis lynx), coyote, wolverine (Gulo gulo), white-tailed deer (Odocoileus virginianus), mule deer (Odocoileus hemonius), bighorn sheep, and moose. For more details, see Hebblewhite et al. (2005).

\section{Human activity}

Humans have widespread presence in the three national parks primarily at valley bottoms and in particular the Bow River Valley. The Canadian Pacific Railway line, Trans Canada Highway (TCH), Highways 93 and 1A, and other lesser-used, secondary two-lane paved roads run through the national parks. Approximately 5 - 6 million people travel through the area annually (Green at al. 1996). Vehicle volumes during 1997-2004 ranged from 50,000 to 800,000 vehicles per month along the TCH, 25,000 to 150,000 vehicles per month along Highway 93, and 4,000 to 100,000 vehicles per month along Highway 1A (Parks Canada, unpublished data). Facilities include the towns of 
Lake Louise and Banff, three ski hills, campgrounds, a golf course, and other tourism related developments. An extensive network of trails along valley bottoms is primarily used for hiking with some biking and equestrian use. In the winter, trails are used for skiing, snowshoeing, and hiking for recreation and access routes for other mountaineering activities. Human activity levels on various trails in the summer range from 100 to 70,000 per month along the Bow River Valley and 0 to 1000 per month in backcountry areas (Parks Canada, unpublished data). Volumes in the winter decrease dramatically with backcountry locations receiving almost no human activity.

To model hourly human activity we obtained data on trails and roads in Banff, Kootenay, and Yoho National Parks from Parks Canada (Fig. 1). Data on 137 trails were gathered using passive (Trafx Research Ltd., Canmore, Alberta, Canada) and active (Goodson \& Associates, Inc., Lenexa, Kansas, USA) infrared counters deployed along trails between 2000 and 2007 (Watson et al. 2000, Cessford and Muhar 2003). We accounted for possible over counting due to false triggers, for example, movements of vegetation by wind, by deleting counts that were $>50 \%$ higher than any other counts on that trail if local park experts also indicated such counts as inexplicably high. Additionally, we only used data from infrared counters that were evaluated by field personnel as reliable. Examples of unreliable infrared counters include those temporarily covered by branches, blocked by spider webs, tampered with, or experiencing malfunctioning hardware issues. Deleted or lost data occurred in $<1 \%$ of the documentation period for all counters. We further assessed data reliability by setting up infrared cameras (Reconyx LLP, Holmen, Wisconsin, USA) simultaneously along infrared counters at five trails. The mean hourly count using infrared cameras on the five documented trails was $0.27(\mathrm{se}=0.11)$ user/ hour less than counts documented by infrared counters. The observed hourly human trail activity in our data ranged from 0 - 1500 users/hour and averaged 1.1 user/hour. We concluded that the slight overestimation ( 0.27 user/hour) of infrared counters resulted in conservative estimates of wildlife and trails in our study. To quantify vehicle activity on roads in the study area, hourly road count data was obtained from the Parks Canada Traffic Count database (Parks Canada, unpublished data).

\section{Wildlife data and habitat selection}

We obtained wolf and elk Global Positioning System (GPS) telemetry locations from previous research in the study area (Hebblewhite and Merrill 2007, Hebblewhite et al. 2008). Twelve wolves (nine females and three males) from four packs were captured between 2002-2004 using modified foothold traps in the summer and helicopter net-gunning and limited aerial darting during the winter, and were outfitted with GPS radio-telemetry collars (GPS3300 model, LOTEK Inc., Newmarket, Ontario, Canada). Wolf location data was collected between December 2002 and July 2005. Twenty female elk were captured between 2002-2004 using corral traps or net-gunning and outfitted with GPS radio-telemetry collars (GPS3300 and 4400 collars, LOTEK Inc., Newmarket, Ontario, Canada). Elk location data were collected between June 2002 and October 2004. Details of wolf and elk capture and monitoring procedures can be found in Hebblewhite and Merrill (2007) and Hebblewhite et al. (2008), respectively. Capture and handling methods were approved under Banff National Park Permit Number B-1994-29 and University of Alberta Animal Care protocol ID\# 35112. All collars were programmed to acquire locations every two hours, which was considered sufficiently temporally accurate to estimate movement parameters of wildlife (Jerde and Visscher 2005).

We investigated resource selection as a function of human activity along roads and trails for these two species using paired or matched-case control logistic regression (Hosmer and Lemeshow 2000, Compton et al. 2002, Whittington et al. 2005). Matched-case control logistic regression, also known as conditional logistic regression, is quickly becoming the recommended method for evaluating resource selection because it appropriately measures availability from a mechanistically biological perspective (Moorcroft and Barnett 2008), and results in robust relative probabilities of selection in a used-availability design (Keating and Cherry 2004). We compared resource selection between telemetry locations and availability measured using 10 random locations paired to each observation. We derived the 10 random locations from the empirical step length and turning angle distribution between consecutive two-hour locations in a classic matched-case control design (Fortin et al. 2005). The distributions for elk were averaged across all individuals, but to account for possible differences between wolf packs, we used step length 
and turning angle distributions from each individual pack. We created random locations using Hawth's Analysis Tools (Beyer 2004) and ArcMap 9.2 (ESRI Inc. 2006), and ensured that each available location did not occur outside the study area. We assigned the date and time of each animal location to the paired random locations. Although habitat induced fix-rate bias is a concern in habitat selection studies (D'Eon et al. 2002, Frair et al. 2004, Hebblewhite et al. 2007), habitat induced GPS-bias was not incorporated into analyses for wolves and elk because rates were $<10 \%$ (Hebblewhite et al. 2007).

\section{Model variables}

In order to model the effects of human activity on wildlife distribution at different distances from trails and roads, we categorized distances to roads and trails using the following distance categories: 0 - 50 m, $51-200 \mathrm{~m}, 201-400 \mathrm{~m}, 401-600 \mathrm{~m}, 601-800$ $\mathrm{m}$, and $>800 \mathrm{~m}$. The $0-50 \mathrm{~m}$ distance represents an animal being on or immediately adjacent to a road or trail. We chose a $50 \mathrm{~m}$ distance as a balance in GPS location accuracy (see Hebblewhite 2006) such that it incorporates an area large enough to include the bulk of locations when an animal is on a trail or road and small enough to minimally include locations away from a trail. In addition, given the temporal resolution of the human activity dataset (+/-1 hour), using categories for distances to trails/ roads seemed appropriate. In sum, using a continuous variable for distance would have exaggerated the inference warranted from wildlife locations' accuracy and from the resolution of the human influence data. We used $800 \mathrm{~m}$ as the upper range to include the area an animal may be displaced to when disturbed. We used $800 \mathrm{~m}$ as the reference category because it was furthest away from human linear features and therefore likely the least affected by human activity. Modeled hourly human activity counts on the trail or road nearest to observed telemetry and random locations were derived using the rules listed below and similar to the human activity model described in Musiani et al. (2010, see also Shepherd and Whittington 2006). Observed human activity counts from the telemetry location date and hour-of-day were obtained from the nearest trail and road (100\% of road data, $28 \%$ of trail data). If this was not available, we used the mean of previous years of human activity of the observed telemetry location month, week, day-of-week, and hour-of-day from the nearest trail or road $(57 \%$ of trail data). If this was not available, we used the average human activity value of the observed telemetry location date and hour-of-day for similar trails and roads (15\% of trail data). Similar trails and roads were defined on a monthly log-scale by Green et al. (1996).

In addition to human activity, we addressed possible confounding effects of other resources by including covariates commonly known to be important predictors of species occurrence in other studies (Mysterud and Ims 1998). We included these covariates in models whether or not they improved model performance to isolate the effects of human activity and distance to trails and roads on species' behaviors. These covariates included slope, elevation, and cover for wolves (Massolo and Meriggi 1998, Kunkel and Pletscher 2000, Ciucci et al. 2003, Mech and Boitani 2003, Oakleaf et al. 2006); and elevation, slope, and greenness as measured by the Normalized Difference Vegetation Index (NDVI; Pettorelli et al. 2005) for elk (Toweill and Thomas 2002, Fortin et al. 2005, Mao et al. 2005, Hebblewhite 2006, Stubblefield et al. 2006). Cover and greenness were derived from Landsat 7 TM satellite imagery (McDermid et al. 2005). Greenness is the measure of herbaceous phytomass and correlates to primary productivity and biomass. Elevation and slope were derived from a $30 \mathrm{~m}^{2}$ Digital Elevation Model (DEM) of the study area.

\section{Analysis}

We tested for wolf and elk selection of areas near trails and roads using separate models for trails and road. We assessed species' responses to these features by comparing models with and without distance, level of human activity, and their interaction. We compared nested models using likelihood ratio tests. We assessed multicollinearity of model variables using the variance inflation factor (VIF), which is a measure of the amount of multicollinearity in a set of multiple regression variables; VIF values $>10$ indicate collinearity. We examined the spatial effects of increasing human activity by estimating relative predicted probabilities of occurrence vs. human activity for each distance category. For each specific level of trail activity the predicted probability for a given distance category was the probability of wildlife occurrence in that distance category compared with other distance categories. The cumulative predicted probabilities of all distance categories for a specific level of trail activity summed to one. We graphed relative 
Table 1. Likelihood ratio test and P-value (significance at $<0.05$ ) results of distance-to-trail/road categorical variable and distance-to-trail/road*hourly trail/road activity categorical interaction variable using nested models for each species. Mean Spearman's rho and P-value of 5-fold cross validation tests performed on models with significant interaction variables.

\begin{tabular}{|c|c|c|c|c|c|}
\hline \multirow[b]{2}{*}{ Explanatory Variable } & & \multicolumn{2}{|c|}{ Trails } & \multicolumn{2}{|c|}{ Roads } \\
\hline & & Wolf & Elk & Wolf & Elk \\
\hline \multirow[t]{2}{*}{ L-R Test of Distance } & $\chi^{2}$ & 33.92 & 58.88 & 28.00 & 9.23 \\
\hline & $P$ & $<0.000$ & $<0.000$ & $<0.000$ & 0.100 \\
\hline \multirow[t]{2}{*}{ L-R Test of Distance * Activity } & $\chi^{2}$ & 12.39 & 44.63 & 17.18 & 11.25 \\
\hline & $P$ & 0.030 & $<0.000$ & 0.004 & 0.047 \\
\hline \multirow[t]{2}{*}{ K-fold Cross Validation of Model } & $\mu$ rho & 0.971 & 0.905 & 0.959 & 0.314 \\
\hline & $\mu P$ & $<0.000$ & 0.002 & $<0.000$ & 0.396 \\
\hline
\end{tabular}

predicted probabilities of occurrence by human activity for each distance category using a linear stretch to scale the relative predicted probabilities between 0 and 1 (Johnson et al. 2004). We assessed the magnitude of response using the derivatives of relative predicted probabilities (Long and Freese 2006).

We used Stata 10 (Stata Corp. L.P. 2008) for statistical analysis. Matched case-control logistic regression was performed using robust variance estimates (Huber-White sandwich estimator) to account for autocorrelation in GPS data (Nielson et al. 2002). For studies in which unbalanced samples occur, sample weighting can be used to rectify unequal observations (Long and Freese 2006). Our research had unequal telemetry observations per animal for elk and per pack for wolves, potentially leading to greater leverage for those animals or packs with more observations. To rectify this, we inversely weighted observations by each animal's or pack's proportion of the total observations, so that all animals for elk or packs for wolves had the same statistical weight in analysis (Long and Freese 2006).

We performed a Spearman's rank correlation based on a case-control $\mathrm{k}$-fold cross validation $(\mathrm{k}=5)$ to assess the predictive capability of each model (Boyce et al. 2002, Fortin et al. 2009). The 5-fold cross validation used $80 \%$ of the data to create a model that predicted the frequency of occurrence of the withheld $20 \%$ using bins that represented the range of predicted RSF scores; the process was repeated five times replacing the withheld $20 \%$.

\section{RESULTS}

\section{Wolf responses to trails}

Wolf use of areas near trails was affected by distance to human activity and trail activity level. The distance-to-trail variable improved model performance $\left(\chi^{2}=33.9, \mathrm{P}<0.0005\right.$; Table 1$)$, and the interaction variable distance-to-trail $*$ trail activity further improved model performance $\left(\chi^{2}=12.4, \mathrm{P}=0.030\right.$; Table 1). Wolf response to increasing trail activity for distance classes $<400 \mathrm{~m}$ differed from distances $>800 \mathrm{~m}(\mathrm{P}<0.05$, Appendix Table A1.1), whereas wolves showed neither selection nor avoidance for distance classes $>400 \mathrm{~m}$ regardless of human activity.

As trail activity increased, wolf selection of areas in distances $0-50 \mathrm{~m}, 51-200 \mathrm{~m}$, and $201-400 \mathrm{~m}$ 
Fig. 2. Graphs of the change in wolf relative probability of use as a function of increasing trail activity within six 'distance-to-trail' categories. The x-axis is hourly trail activity and y-axis is relative probability of use. A linear stretch was used to scale the predicted values between 0 and 1 following Johnson et al. (2004).
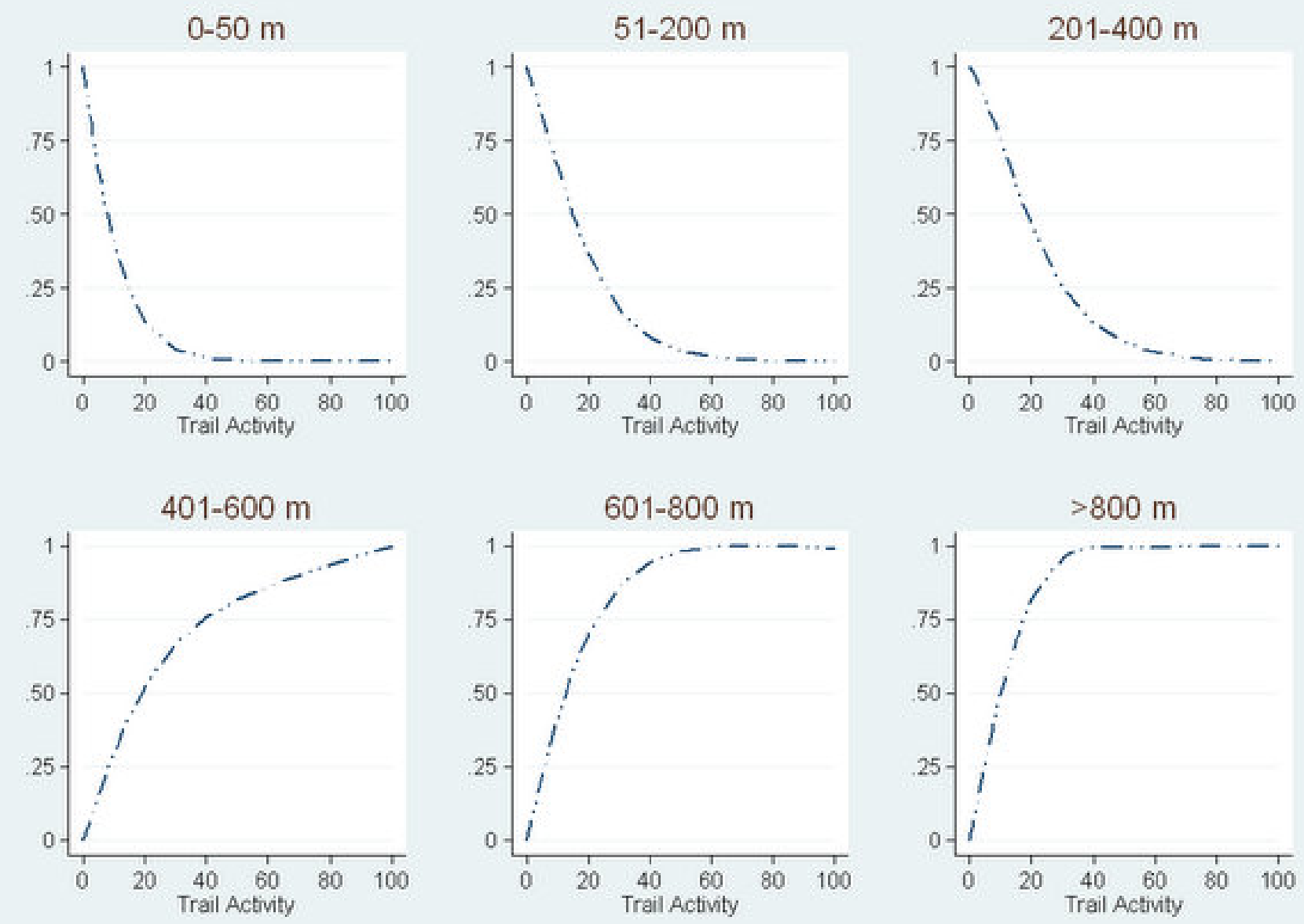

decreased (Fig. 2). Conversely, wolf selection of areas in distances $401-600 \mathrm{~m}, 601-800 \mathrm{~m}$, and > $800 \mathrm{~m}$ increased with increasing trail activity (Fig. 2 ). Wolf response changed from avoidance of distances $<400 \mathrm{~m}$ to attraction of distances $>400$ $m$ with increasing trail activity, because wolves may move from areas $<400 \mathrm{~m}$ to $>400 \mathrm{~m}$ from trails. Wolf responses to increasing trail activity leveled off for all distances at higher trail activity levels (Fig. 2). Derivatives were lowest (decreasing slope) in areas near trails, suggesting wolves had a stronger and quicker avoidance of human activity near trails (Table 2). Elevation, slope, and cover were strong predictors of wolf occurrence $(\mathrm{P}<0.05$, Appendix Table A1.1). The mean VIF for all variables was 1.23 and no VIF was greater than 2, indicating minimal collinearity. The 5-fold cross validation had a mean Spearman's rank correlation of $0.97(\mathrm{P}$ $<0.0005)$ indicating that the model predicted the distribution of wolves accurately (Table 1). 
Table 2. Hourly human activity at the peak negative derivative. 'Peak derivative level' represents the greatest rate of negative change in probability of use of locations within listed distances-to-trails/roads. Distance-to-trail/road categories that did not have negative derivatives were not included. $\dagger=$ Derivative was continuously negative. N/A = Not applicable.

\begin{tabular}{|c|c|c|c|c|c|}
\hline Species & $\begin{array}{l}\text { Human } \\
\text { Activity } \\
\text { Type }\end{array}$ & $\begin{array}{l}\text { Distance from } \\
\text { Trail or Road (m) }\end{array}$ & $\begin{array}{c}\text { Peak Negative } \\
\text { Derivative } \\
\text { Level }\end{array}$ & $\begin{array}{c}\text { Hourly Human } \\
\text { Activity Level at Peak } \\
\text { Negative Derivative }\end{array}$ & $\begin{array}{l}\text { Hourly Human Activity Level } \\
\text { When Species Began Avoidance }\end{array}$ \\
\hline \multirow[t]{5}{*}{ Elk } & Trail & $0-50$ & -0.05116 & $<1$ & $\dagger$ \\
\hline & & $51-200$ & -0.00477 & 8 & 1 \\
\hline & & $201-400$ & -0.00463 & 10 & 2 \\
\hline & & $401-600$ & -0.00355 & 45 & 12 \\
\hline & & $601-800$ & -0.00345 & 45 & 12 \\
\hline \multirow[t]{6}{*}{ Wolves } & Trail & $0-50$ & -0.01540 & $<1$ & N/A \\
\hline & & $51-200$ & -0.00639 & 8 & N/A \\
\hline & & $201-400$ & -0.00540 & 10 & N/A \\
\hline & Road & $0-50$ & -0.00026 & 25 & N/A \\
\hline & & $51-200$ & -0.00008 & 700 & N/A \\
\hline & & $201-400$ & -0.00001 & 1500 & N/A \\
\hline
\end{tabular}

\section{Wolf responses to roads}

The distance-to-road variable improved model performance $\left(\chi^{2}=28.0, \mathrm{P}<0.0005\right.$; Table 1$)$. The interaction variable distance-to-road*road activity further improved model performance $\left(\chi^{2}=17.2, \mathrm{P}\right.$ $=0.004 ;$ Table 1$)$. Wolf response to increasing road activity at distances $0-200 \mathrm{~m}$ was significantly different than for distances $>800 \mathrm{~m}(\mathrm{P}<0.05$, Appendix Table A1.2).

As road activity increased, wolf selection progressively changed from avoidance $(<200 \mathrm{~m})$ to neutral $(201-400 \mathrm{~m})$ to attraction $(>400 \mathrm{~m}$; Fig. 3 ), suggesting that wolves at distances $<200 \mathrm{~m}$ move to distances $>400 \mathrm{~m}$ as road activity increases. Wolf selection for the $201-400 \mathrm{~m}$ distance changed from mild attraction to mild avoidance at the road activity level of $\sim 1500$ vehicles/hr (Table 2). Derivatives were lowest near roads, suggesting a greater avoidance response to human activity when animals were nearer to roads (Table 2). Elevation, slope, and cover were strong predictors of wolf occurrence $(\mathrm{P}<0.05$, Appendix Table A1.2). The mean VIF for all variables was 1.81 and no VIF was greater than 4 , indicating minimal collinearity. The 5-fold cross validation had a mean Spearman's rank correlation of $0.96(\mathrm{P}<0.0005)$ indicating that the model consistently predicted the distribution of wolves (Table 1).

\section{Elk responses to trails}

The categorical distance-to-trail variable improved model performance $\left(\chi^{2}=58.88, \mathrm{P}<0.05\right.$; Table 1$)$. The interaction variable distance-to-trail*trail activity further improved model performance $\left(\chi^{2}=\right.$ $44.63, \mathrm{P}=0.05$; Table 1$)$. Elk response to increasing trail activity at distances $201-400 \mathrm{~m}$ and $601-800$ $\mathrm{m}$ was significantly different than for distances > $800 \mathrm{~m}(\mathrm{P}<0.05$, Appendix Table A1.3). 
Fig. 3. Graphs of the change in wolf relative probability of use as a function of increasing road activity within six 'distance-to-road' categories. The $\mathrm{x}$-axis is hourly road activity and $\mathrm{y}$-axis is relative probability of use. A linear stretch was used to scale the predicted values between 0 and 1 following Johnson et al. (2004).
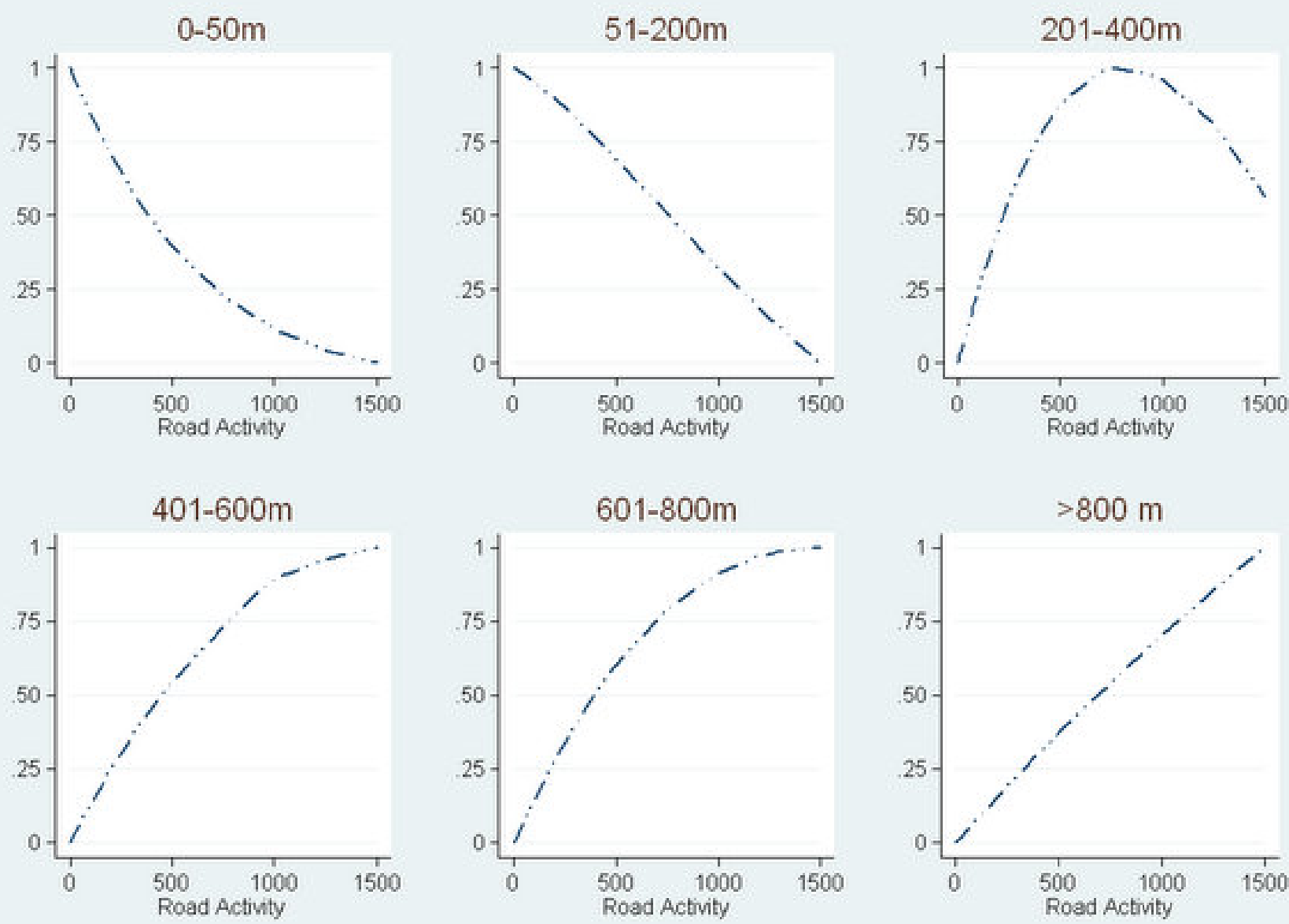

As trail activity increased, elk selection of locations in distance $0-50 \mathrm{~m}$ immediately and sharply decreased, than leveled off at between 10 - 20 users/ hour (Fig. 4). Elk responded to increasing trail activity at distances $51-400 \mathrm{~m}$ initially with mild attraction; then avoided these distances when trail activity reached one to two users/hr (Table 2, Fig. 4). Similarly, elk at distances $401-800 \mathrm{~m}$ responded to increasing trail activity with attraction; then avoided these distances when trail activity reached $\sim 12$ users/hr. Derivatives were lowest near trails, suggesting a greater avoidance response to human activity when animals were nearer to trails (Table $2)$. Elevation, slope, and greenness were strong predictors of elk occurrence $(\mathrm{P}<0.05$, Appendix Table A1.3). The mean VIF for all variables was 1.34 and no VIF was greater than 3 , indicating minimal collinearity. The 5 -fold cross validation had a mean Spearman's rank correlation of 0.91 (P $=0.002$ ) indicating that the model consistently predicted the distribution of elk (Table 1). 
Fig. 4. Graphs of the change in elk relative probability of use as a function of increasing trail activity within six 'distance-to-trail' categories. The $\mathrm{x}$-axis is hourly trail activity and y-axis is relative probability of use. A linear stretch was used to scale the predicted values between 0 and 1 following Johnson et al. (2004).
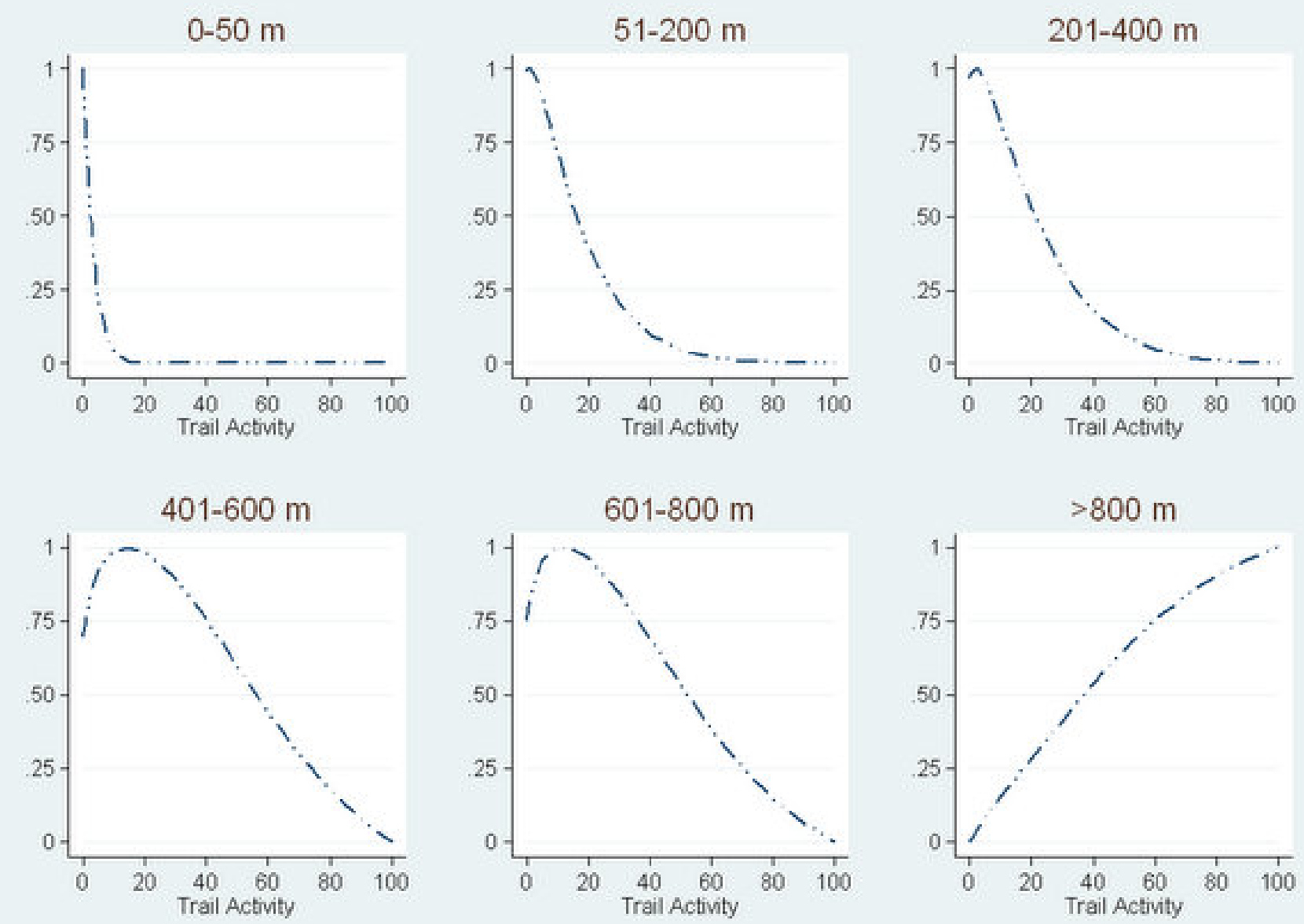

\section{Elk responses to roads}

The categorical distance-to-road variable did not on its own improve model performance $\left(\chi^{2}=9.23, \mathrm{P}\right.$ $=0.100 ;$ Table 1$)$. However, the interaction variable distance-to-roads*road activity was a predictor of elk occurrence $\left(\chi^{2}=11.25, \mathrm{P}=0.047\right.$; Table 1$)$. Elk selected for lower elevations and higher greenness $(\mathrm{P}<0.05$, Appendix Table A1.4) but not lower slopes (P >0.05, Appendix Table A1.4). The mean VIF for all variables was 1.63 and no VIF was greater than 3, indicating minimal collinearity. The 5-fold cross validation had a mean Spearman's rank correlation of $0.31(\mathrm{P}=0.396)$ indicating that the model did not consistently predict the distribution of elk (Table 1). As the model did not consistently predict elk distribution, relative predicted probabilities were not calculated for the elk near roads model.

\section{DISCUSSION}

\section{Wolf and elk avoidance of human activity}

Our study documented clear changes in habitat selection patterns by wolves and elk in response to increased human activity with marked implications 
for their ecology and community interactions. We found wolves and elk selected areas farther away from trails and roads with increasing human activity (Figs. 2-4). For example, as human activity increased, wolf relative probability of use decreased in areas $<400 \mathrm{~m}$ and increased in areas $>400 \mathrm{~m}$ from trails. Similarly, elk responded to increasing human activity on trails by progressively decreasing their relative probability of use in areas $<800 \mathrm{~m}$. In particular, elk seemed to prefer areas at distances 401 - $800 \mathrm{~m}$ from trails (medium distances) over those $>800 \mathrm{~m}$ at low levels of human activity. However, those elk located at medium distances from trails were avoiding human activity as it increased. In accordance with our findings, previous research observed that wolves in Jasper National Park, Canada more strongly selected low activity trails compared with high activity trails (Whittington et al. 2005), wolves in Scandinavia fled from an approaching human when between 17 and $310 \mathrm{~m}$ away (Karlsson et al. 2007), and wolves in Finland showed greatest human-avoidance at the most heavily used roads (Kaartinen et al. 2005). Elk and other ungulates have displayed similar behavior in response to increasing human activity. For example, Wisdom et al. (2004) found that elk were provoked to flee more frequently during higher levels of trail activity and Keller and Bender (2007) found that increased human presence negatively affected bighorn sheep use of a preferred mineral lick site. Our research found insufficient evidence of elk response to road activity. In contrast to this, other research has found negative effects of road activity on elk and other ungulates. In other studies, elk occurred at greater distances to open than closed roads (Ager et al. 2003) and were found to decrease their use in areas $<200 \mathrm{~m}$ from roads at increasing vehicle activity (Gagnon et al. 2007). Similarly, Dussault et al. (2007) found that moose increased their movement rates near roads and Papouchis et al. (2001) found that bighorn sheep were found $39 \%$ farther from roads in a high-use area than in a lowuse area. A possible reason for this contrast may be the mountainous topography of our study area in which both roads and optimal elk foraging habitat might occur at valley bottoms (Dodd et al. 2007).

We found that wolves and elk located closer to trails or roads displayed greater avoidance rates at similar human activity levels than those farther away. For example, wolves and elk at locations $0-50 \mathrm{~m}$ from trails reduced their relative probability of occurrence at a faster rate than those at $51-200 \mathrm{~m}$ as human activity increased. Similarly, Wisdom et al. (2004) documented elk movement rates and flight response probabilities were substantially higher during higher levels of trail activity in Oregon. By identifying derivatives of relative probability of use, we also found that at closer distances to trails, and roads for wolves, smaller human activity levels were required to invoke avoidance responses.

Human activity may be an important factor in predator-prey interactions (Kunkel and Pletscher 2000, Hebblewhite et al. 2005, Hebblewhite and Merrill 2008). Previous research has found that human activity may lead to universal avoidance. For example, Mech and Boitani (2003) found that wolves learned to avoid humans to decrease their own mortality risk and Cassirer et al. (1992) found elk avoided even small numbers of humans. Conversely, in other systems a differential response to human activity according to trophic level resulted in cascading trophic interactions (Hebblewhite et al. 2005, Berger 2007).

We observed a complex interaction between the distance animals were located from trails and human activity levels resulting in species adopting both mutual avoidance and differential response behaviors. Close distances to trails appeared to mediate a mutual avoidance response by both wolves and elk. Both species avoided areas $50 \mathrm{~m}$ or less from trails in response to low levels of human activity. Wolf and elk responses in areas between 50 - $400 \mathrm{~m}$ from trails were dependent on the level of human activity. At low levels of human activity differential responses could be mediating trophic interactions. Wolves responded to low levels of human activity by avoiding areas $50-400 \mathrm{~m}$. Conversely, elk responded to similar levels of human activity by initially increasing their use in these areas, perhaps taking advantage of the refugia created from the reduced likelihood of predators in general. Consistent with this interpretation, wolf avoidance of human activity has been described in many other systems (Thurber et al. 1994, Theuerkauf et al. 2003, Kaartinen et al. 2005, Whittington et al. 2005), and a study conducted in the study area (Hebblewhite and Merrill 2007) showed that ungulates can exploit this to reduce their own predation risk. In our study area, wolves are the main predators of elk (Hebblewhite et al. 2002). However, elk might need to minimize the risk of being predated upon also by other predators, including cougars (Kortello et al. 2007) and black and grizzly bears (Herrero 2005). Whereas little is 
known for cougars and black bears, a large body of information demonstrates grizzly bear spatial avoidance of humans at higher levels of use in the study area (Gibeau et al. 2002, Chruszcz et al. 2003). Therefore, similar speculation is warranted for wolves, grizzly bears, and perhaps other predators of elk, because large mammalian predators are known to avoid humans in other areas (Kasworm and Manley 1990, Trombulak and Frissell 2000, George and Crooks 2006). However, once human activity levels were greater than two persons per hour, wolves and elk once again responded with mutual avoidance of areas 50 - $400 \mathrm{~m}$ from trails, resulting in the indirect loss of important montane habitat.

During low human activity, wolves in our study were more likely to be at locations between 0 - 50 $\mathrm{m}$ than distances $>400 \mathrm{~m}$ from trails (Appendix Table A1.5). This corroborates previous findings indicating that wolves may use linear features with low levels of human activity for travel routes (Thurber et al. 1994, Callaghan 2002) because these features may allow wolves ease of travel (James and Stuart-Smith 2000). Other research conducted in the Canadian Rocky Mountains similarly found wolves preferred areas $<25 \mathrm{~m}$ from roads and trails (Whittington et al. 2005). Wolves preferring to travel on or near linear features for short durations (under two hours) might explain our research not detecting a significant selection for areas $0-50 \mathrm{~m}$ compared with areas $51-400 \mathrm{~m}$ from trails (Whittington et al. 2004).

\section{Confounding factors in human effects on habitat use}

Trails and roads in our study area often occur in high quality habitat along valley bottoms and often near streams and rivers. We included elevation as a covariate to control for this effect, however wolf and elk use of high quality habitat and narrow travel corridors near roads and trails could have reduced the displacement effects we observed (Kunkel and Pletscher 2000, Hebblewhite et al. 2005). Interestingly, trails had a stronger spatial effect on wolf and elk resource selection than roads. One reason for this result could be that animals in our study area regularly used wildlife crossing structures to cross the Trans Canada Highway (Clevenger et al. 2001) perhaps resulting in less apprehension of approaching and crossing roads. In addition, hiding cover and topographical features may be important factors that affect animal response
(Hewison et al. 2001, Ager et al. 2003). For example, in the presence of hiding cover or nearby ridges wildlife may be more likely to tolerate being closer to human presence (Cassirer et al. 1992). It is possible that some animals in our study exhibited attenuated responses to human activity because of such features, which were not accounted for by our methodological approach.

We attempted to account for confounding factors by including the commonly found habitat and topographical factors important to each species. However, other factors such as snow conditions, topography, or variability in individual behavior may have affected our results (Hebblewhite and Merrill 2008). For example, Cassirer et al. (1992) observed that the distance moved by elk in Yellowstone National Park after being disturbed by cross country skiers ranged widely and was related to distance to nearest ridge. Future research might investigate the relative importance of other covariates with human activity at increasing distances to roads and trails to assess their relative importance to selection (Rowland et al. 2000). We used the human activity level of the nearest trail/ road to a wildlife telemetry location as an indicator of human presence when assessing effects to wildlife. We acknowledge that wildlife may have been affected by other trails/roads further away from our documented trail/road, but with higher human activity levels. Such additional effects on wildlife movements in theory have the potential to confound, attenuate, or obscure the responses found in this study. Trails in our mountainous study area generally occurred on valley bottoms that were $>2$ $\mathrm{km}$ from their nearest trail. Consequently, the disturbance effects produced by the second nearest trail or road might have been eliminated or at least attenuated, because of the rugged mountainous terrain of our study area separating trails, resulting in topographic obstacles existing between wildlife and multiple locations of human use. Wildlife locations that occurred near trail intersections may have incurred effects from both trails. We believe these effects were minimal in our research, considering that opportunities where a high activity trail intersects with or occurs within close proximity of a low activity trail were very few in our study area. In fact, high activity trails/roads occurred in proximity to other high activity trails/roads, as was similar for low-use areas. Future research might investigate cumulative disturbance from human activity also incorporating approaches such as density indexes over the landscape. 


\section{Implications}

Our study documented marked responses to human activity by a top predator and by a dominant herbivore species (Witmer and deCalesta 1985, Thurber et al. 1994, Shepherd and Whittington 2006). The responses to human activity we documented for wolves and elk may have energetic costs similar to anti-predator behaviors (Frid and Dill 2002). Duchesne et al. (2000) observed that woodland caribou increased time spent in vigilance behavior at the expense of foraging as eco-tourist visits increased in the Charlevoix Biosphere Reserve, Canada. Cassirer et al. (1992) estimated that elk needed to consume an additional $295 \mathrm{~g} /$ day of forage to compensate for movement away from cross country skiers in Yellowstone National Park. Greater energy requirements and reduced foraging time caused by anthropogenic disturbance can impair animal fitness (Frid and Dill 2002). Our research did not directly investigate energetic costs. However, proper identification and management of human disturbance near trails and roads may be important to mitigate a possible predation risk response and its associated effects.

The human mediated changes in both humanwildlife and predator-prey interactions may lead to undesirable consequences. Differential habituation among and within species may lead to changes in predator-prey dynamics (Caro 2005). For example, differential displacement away from human presence resulted in unequal predation risks of migrant vs. resident elk in our study area (Robinson et al. 2010). Additionally, wolf exclusion caused by humans led to changes in elk population dynamics (Hebblewhite et al. 2002) and cascading trophic effects on aspen (Populus tremuloides), willow (Salix spp.), beaver (Castor Canadensis), and songbirds (Hebblewhite et al. 2005). In this view, the role of humans may equally apply to wolves, elk, and to other potential species affected as humans may de facto serve the role of the nonconsumptive keystone predator (Boyle and Samson 1985).

Our research documented differential influences on wolves and elk that were dependent on the level of human activity, with the latter possibly benefiting from predator displacement by humans. Studies could be conducted in the future on other carnivore and herbivore species to highlight similar mechanisms across ecosystems. Additionally, future research focusing on the likelihood of returning to disturbance areas would be useful to further address possible long term behavioral consequences attributed to human activity because some studies have suggested persistent low levels of disturbance may lessen the likelihood of returning to previously used areas (Kuck et al. 1985) and lead to permanent shifts in habitat use (Rowland et al. 2000), whereas other studies found animals returned when activity lowered or desisted (Casirer et al. 1992, Gagnon et al 2007).

Understanding how human activity affects species distribution has great importance in areas such as ours where topography limits suitable habitat. Suitable habitat is limited by rock, ice, and steep rugged terrain in the mountainous landscape of Banff, Kootenay, and Yoho National Parks (Gibeau et al. 2001). The anthropogenic infrastructure that is required to support a town, transportation, and tourism related industry also reduces suitable habitat on valley bottoms in mountainous areas. The combination of these conditions may threaten species viability via higher rates of mortality (Benn and Herrero 2002, McNay 2002), habitat fragmentation (Alexander et al. 2005), and reduced habitat security and species resiliency (Weaver et al. 1996, Gibeau et al. 2001). Additional disturbance initiated by human activity, as documented in our study, at otherwise suitable habitats surrounding trails and roads that often occur on valley bottoms may further reduce species viability.

The circadian cycle has been the finest temporal scale used by previous studies that associate wildlife distribution to human activity. Our research documented that wildlife avoidance occurs at finer spatio-temporal scales than previously studied. We found that wolf and elk selection of locations near trails and roads was dependent on hourly human activity levels and the distance to the human linear feature. A failure to properly address the scale at which wildlife respond to human activity could lead to mistaken conclusions about habitat selection. Proper assessment of the relationship between finescale human activity and wildlife distribution may have important implications for animal energy budgets, human-wildlife and predator-prey interactions, ecological trophic cascades, and wildlife viability. 
Responses to this article can be read online at: http://www.ecologyandsociety.org/voll6/iss3/art16/ responses/

\section{Acknowledgments:}

We thank our funding partners: Parks Canada, the University of Calgary, ACA Challenge Grants in Biodiversity, ACA Grant Eligible Conservation Fund, Foothills Model Forest-Chisholm-Dogrib Fire initiative grants, Sundre Forest Products LTD., Canon National Parks Science Scholarship for the Americas, Rocky Mountain Elk Foundation, University of Alberta, and a NSERC Discovery grant. We would also like to acknowledge the following for their input and advice toward this project: Cormack Gates, Tom Hurd, Alessandro Massolo, Tom Davidson, Tao Gui, Cathy Hourigan, Greg McDermid, Jean-Gabriel Hasbani, Kathy Rettie, Mike Gibeau, Gordon Stenhouse, Parks Canada, Alberta Sustainable Resource Development, Tyler Muhly, Joann Skilnik, Paul Paquet, Sk. Morshed Anwar, Rick Smee, Darren Labonte, James R. Allen, Tom Daniels, Barry McElhinney, Ian Pengelly, Darrel Zell, Johnny and Marie Nylund, Rick and Jean Smith, and finally the two anonymous reviewers for their invaluable comments on the manuscript.

\section{LITERATURE CITED}

Ager, A. A., B. K. Johnson, J. W. Kern, and J. G. Kie. 2003. Daily and seasonal movements and habitat use by female Rocky Mountain elk and mule deer. Journal of Mammalogy 84(3):1076-1088. htt p://dx.doi.org/10.1644/BBa-020

Alexander, S. M., N. M. Waters, and P. C. Paquet. 2005. Traffic volume and highway permeability for a mammalian community in the Canadian Rocky Mountains. Canadian Geographer 49(4):321-331. http://dx.doi.org/10.1111/j.0008-3658.2005.00099. $\underline{\mathrm{X}}$

Anderson, D. P., M. G. Turner, J. D. Forester, J. Zhu, M. S. Boyce, H. Beyer, and L. Stowell. 2005. Scale-dependent summer resource selection by reintroduced elk in Wisconsin, USA. Journal of Wildlife Management 69:298-310. http://dx.doi.org /10.2193/0022-541X(2005)069<0298:SSRSBR>2.0. $\mathrm{CO} ; 2$
Baker, W. L. 1992. The landscape ecology of large disturbances in the design and management of nature reserves. Landscape Ecology 7(3):181-194. http://dx.doi.org/10.1007/BF00133309

Benn, B., and S. Herrero. 2002. Grizzly bear mortality and human access in Banff and Yoho National Parks, 1971-98. Ursus 13:213-221.

Berger, J. 2007. Fear, human shields and the redistribution of prey and predators in protected areas. Royal Society: Biology Letters 3(6):620-623. http://dx.doi.org/10.1098/rsbl.2007.0415

Berger, J., P. B. Stacey, L. Bellis, and M. P. Johnson. 2001. A mammalian predator-prey imbalance: grizzly bear and wolf extinction affect avian neotropical migrants. Ecological Applications 11 (4):947-960. http://dx.doi.org/10.2307/3061004

Beyer, H. L. 2004. Hawth's analysis tools for ArcGIS. [online] URL: http://www.spatialecology. com/index.php

Boyce, M. S., P. R. Vernier, S. E. Nielsen, and F. K. A. Schmiegelow. 2002. Evaluating resource selection functions. Ecological Modelling 157 (2-3):281-300. http://dx.doi.org/10.1016/S0304-3800 (02)00200-4

Boyle, S. A., and F. B. Samson. 1985. Effects of nonconsumptive recreation on wildlife: a review. Wildlife Society Bulletin 13(2):110-116.

Brooks, T. M., R. A. Mittermeier, C. G. Mittermeier, G. A. B. da Fonseca, A. B. Rylands, W. R. Konstant, P. Flick, J. Pilgrim, S. Oldfield, G. Magin, and C. Hilton-Taylor. 2002. Habitat loss and extinction in the hotspots of biodiversity. Conservation Biology 16(4):909-923. http://dx.doi.org/10.1046/j.1523-17 $\underline{39.2002 .00530 . x}$

Buehler, D. A., T. J. Mersmann, J. D. Fraser, and J. K. D. Seegar. 1991. Effects of human activity on Bald Eagle distribution on the northern Chesapeake Bay. Journal of Wildlife Management 55 (2):282-290. http://dx.doi.org/10.2307/3809151

Callaghan, C. J. 2002. The ecology of gray wolf (Canis lupus) habitat use, survival, and persistence in the central Rocky Mountains, Canada. Dissertation. Faculty of Graduate Studies, University of Guelph, Guelph, Ontario, Canada. 
Caro, T. 2005. Antipredator defenses in birds and mammals. University of Chicago Press, Chicago, Illinois, USA.

Cassirer, E. F., D. J. Freddy, and E. D. Ables. 1992. Elk responses to disturbance by cross-country skiers in Yellowstone National Park. Wildlife Society Bulletin 20(4):375-381.

Cessford, G., and A. Muhar. 2003. Monitoring options for visitor numbers in national parks and natural areas. Journal for Nature Conservation 11 (4):240-250. http://dx.doi.org/10.1078/1617-1381-00055

Ciucci, P., L. Boitani, F. Francisci, and G. Andreoli. 1997. Home range, activity and movements of a wolf pack in central Italy. Journal of Zoology 243 (4):803-819. http://dx.doi.org/10.1111/j.1469-7998 1997.tb01977.x

Ciucci, P., L. Boitani, and M. Masi. 2003. Winter habitat and travel route selection by wolves in the northern Apennines, Italy. Ecography 26 (2):223-235. http://dx.doi.org/10.1034/j.1600-0587 .2003.03353.x

Clevenger, A. P., B. Chruszcz, and K. E. Gunson. 2001. Highway mitigation fencing reduces wildlifevehicle collisions. Wildlife Society Bulletin 29 (2):646-653.

Compton, B. W., J. M. Rhymer, and M. McCollough. 2002. Habitat selection by wood turtles (Clemmys insculpta): an application of paired logistic regression. Ecology 83(3):833-843. http://d x.doi.org/10.2307/3071885

Chruszcz, B., A. P. Clevenger, K. E. Gunson, and M. L. Gibeau. 2003. Relationships among grizzly bears, highways, and habitat in the Banff-Bow Valley, Alberta, Canada. Canadian Journal of Zoology 81(8):1378-1391. http://dx.doi.org/10.1139/ $\underline{\mathrm{z} 03-123}$

D'Eon, R. G., R. Serrouya, G. Smith, and C. O. Kochanny. 2002. GPS radiotelemetry error and bias in mountainous terrain. Wildlife Society Bulletin 30 (2):430-439.

Dodd, N. L., J. W. Gagnon, S. Boe, and R. E. Schweinsburg. 2007. Assessment of elk highway permeability by using global positioning system telemetry. Journal of Wildlife Management 71 (4):1107-1117. http://dx.doi.org/10.2193/2006-106
Duchesne, M., S. D. Côté, and C. Barrette. 2000. Responses of woodland caribou to winter ecotourism in the Charlevoix Biosphere Reserve, Canada. Biological Conservation 96(3):311-317. http://dx.doi.org/10.1016/S0006-3207(00)00082-3

Dussault, C., J.-P. Ouellet, C. Laurian, R. Courtois, M. Poulin, and L. Breton. 2007. Moose movement rates along highways and crossing probability models. Journal of Wildlife Management 71 (7):2338-2345. http://dx.doi.org/10.2193/2006-499

Dyer, S. J., J. P. O'Neill, S. M. Wasel, and S. Boutin. 2001. Avoidance of industrial development by woodland caribou. Journal of Wildlife Management 65(3):531-542. http://dx.doi.org/10.2307/3803106

Forman, R. T. T., and L. E. Alexander. 1998. Roads and their major ecological effects. Annual Review of Ecology and Systematics 29(1):207-231. http://d x.doi.org/10.1146/annurev.ecolsys.29.1.207

Fortin, D., H. L. Beyer, M. S. Boyce, D. W. Smith, T. Duchesne, and J. S. Mao. 2005. Wolves influence elk movements: behavior shapes a trophic cascade in Yellowstone National Park. Ecology 86:1320-1330. http://dx.doi.org/10.1890/04-0953

Fortin, D., M.-E. Fortin, H. L. Beyer, T. Duchesne, S. Courant, and K. Dancose. 2009. Group-sizemediated habitat selection and group fusionfission dynamics of bison under predation risk. Ecology 90(9):2480-2490. http://dx.doi.org/10.189 $\underline{0 / 08-0345.1}$

Frair, J. L., S. E. Nielsen, E. H. Merrill, S. R. Lele, M. S. Boyce, R. H. M. Munro, G. B. Stenhouse, and H. L. Beyer. 2004. Removing GPS collar bias in habitat selection studies. Journal of Applied Ecology 41(2):201-212. http://dx.doi.org/10.1111/j $.0021-8901.2004 .00902 . \mathrm{x}$

Freddy, D. J., W. M. Bronaugh, and M. C. Fowler. 1986. Responses of mule deer to disturbance by persons afoot and snowmobiles. Wildlife Society Bulletin 14(1):63-68.

Frid, A., and L. M. Dill. 2002. Human-caused disturbance stimuli as a form of predation risk. Conservation Ecology 6(1): 11. [online] URL: http ://www.consecol.org/vol6/iss1/art11/ 
Gagnon, J. W., T. C. Theimer, N. L. Dodd, S. Boe, and R. E. Schweinsburg. 2007. Traffic volume alters elk distribution and highway crossings in Arizona. Journal of Wildlife Management 71(7):2318-2323. http://dx.doi.org/10.2193/2006-224

George, S. L., and K. R. Crooks. 2006. Recreation and large mammal activity in an urban nature reserve. Biological Conservation 133(1):107-117. http://dx.doi.org/10.1016/j.biocon.2006.05.024

Gibeau, M. L., A. P. Clevenger, S. Herrero, and J. Wierzchowski. 2002. Grizzly bear response to human development and activities in the Bow River Watershed, Alberta, Canada. Biological Conservation 103(2):227-236. http://dx.doi.org/10.1016/S0006-3207 (01)00131-8

Gibeau, M. L., S. Herrero, J. Kansas, and B. Benn. 1996. Grizzly bear population and habitat status in Banff National Park. Chapter 6 in J. Green, C. Pacas, L. Cornwell, and S. Bayley, editors. Ecological outlooks project. A cumulative effects assessment and futures outlook of the Banff Bow Valley. Prepared for the Banff Bow Valley study, Department of Canadian Heritage, Ottawa, Ontario, Canada.

Gibeau, M. L., S. Herrero, B. N. McLellan, and J. G. Woods. 2001. Managing for grizzly bear security areas in Banff National Park and the central Canadian Rocky Mountains. Ursus 12:121-130.

Green, J., C. Pacas, L. Cornwell, and S. E. Bayley. 1996. Ecological outlook cumulative effects assessment and futures outlook of the Banff Bow Valley: final report. Department of Canadian Heritage, Ottawa, Ontario, Canada.

Hebblewhite, M. 2006. Linking predation risk and forage to ungulate population dynamics. Dissertation. Department of Biological Sciences, University of Alberta, Edmonton, Alberta, Canada.

Hebblewhite, M., and E. Merrill. 2007. Multiscale wolf predation risk for elk: does migration reduce risk? Oecologia 152(2):377-387. http://dx.doi.org/1 $\underline{0.1007 / \mathrm{s} 00442-007-0661-\mathrm{y}}$

Hebblewhite, M., and E. Merrill. 2008. Modelling wildlife-human relationships for social species with mixed-effects resource selection models. Journal of Applied Ecology 45(3):834-844. http://dx.doi.org/1 $\underline{0.1111 / j .1365-2664.2008 .01466 . x}$
Hebblewhite, M., E. Merrill, and G. McDermid. 2008. A multi-scale test of the forage maturation hypothesis in a partially migratory ungulate population. Ecological Monographs 78(2)141-166. http://dx.doi.org/10.1890/06-1708.1

Hebblewhite, M., M. Percy, and E. H. Merrill. 2007. Are all global positioning system collars created equal? Correcting habitat-induced bias using three brands in the central Canadian Rockies. Journal of Wildlife Management 71(6):2026-2033. http://dx.do i.org/10.2193/2006-238

Hebblewhite, M., M. Percy, and R. Serrouya. 2003. Black bear (Ursus americanus) survival and demography in the Bow Valley of Banff National Park, Alberta. Biological Conservation 112 (3):415-425. http://dx.doi.org/10.1016/S0006-3207 (02)00341-5

Hebblewhite, M., D. H. Pletscher, and P. C. Paquet. 2002. Elk population dynamics in areas with and without predation by recolonizing wolves in Banff National Park, Alberta. Canadian Journal of Zoology 80(5):789-799. http://dx.doi.org/10.1139/z 02-058

Hebblewhite, M., C. A. White, C. G. Nietvelt, J. A. McKenzie, T. E. Hurd, J. M. Fryxell, S. E. Bayley, and P. C. Paquet. 2005. Human activity mediates a trophic cascade caused by wolves. Ecology 86 (8):2135-2144. http://dx.doi.org/10.1890/04-1269

Herrero, S., editor. 2005. Biology, demography, ecology and management of grizzly bears in and around Banff National Park and Kananaskis Country: the final report of the Eastern Slopes Grizzly Bear Project. Faculty of Environmental Design, University of Calgary, Calgary, Alberta, Canada.

Hewison, A. J. M., J. P. Vincent, J. Joachim, J. M. Angibault, B. Cargnelutti, and C. Cibien. 2001. The effects of woodland fragmentation and human activity on roe deer distribution in agricultural landscapes. Canadian Journal of Zoology 79 (4):679-689. http://dx.doi.org/10.1139/z01-032

Hobbs, R. J., and L. F. Huenneke. 1992. Disturbance, diversity, and invasion: implications for conservation. Conservation Biology 6 (3):324-337. http://dx.doi.org/10.1046/j.1523-1739 .1992.06030324.x 
Holland, W. D., and G. M. Coen, editors. 1983. Ecological (biophysical) land classification of Banff and Jasper National Parks. Volume 1: summary. Alberta Institute of Pedology, Edmonton, Alberta, Canada.

Holroyd, G. L., and K. J. Van Tighem. 1983. Ecological (biophysical) land classification of Banff and Jasper National Parks. Volume 3: the wildlife inventory. Canadian Wildlife Service, Edmonton, Alberta, Canada.

Hosmer, D. W., and S. Lemeshow. 2000. Applied logistic regression. Second edition. John Wiley and Sons, New York, New York, USA. http://dx.doi.org/ http://dx.doi.org/10.1002/0471722146

James, A. R. C., and A. K. Stuart-Smith. 2000. Distribution of caribou and wolves in relation to linear corridors. Journal of Wildlife Management 64 (1):154-159. http://dx.doi.org/10.2307/3802985

Jedrzejewski, W., K. Schmidt, J. Theuerkauf, B. Jedrzejewska, and H. Okarma. 2001. Daily movements and territory use by radio-collared wolves (Canis lupus) in Bialowieza Primeval Forest in Poland. Canadian Journal of Zoology 79:1993-2004.

Jerde, C. L., and D. R. Visscher. 2005. GPS measurement error influences on movement model parameterization. Ecological Applications 15(3) 806-810. http://dx.doi.org/10.1890/04-0895

Johnson, C. J., D. R. Seip, and M. S. Boyce. 2004. A quantitative approach to conservation planning: using resource selection functions to map the distribution of mountain caribou at multiple spatial scales. Journal of Applied Ecology 41(2):238-251. http://dx.doi.org/10.1111/j.0021-8901.2004.00899. $\underline{\mathrm{x}}$

Kaartinen, S., I. Kojola, and A. Colpaert. 2005. Finnish wolves avoid roads and settlements. Annales Zoologici Fennici 42:523-532.

Karlsson, J., M. Eriksson, and O. Liberg. 2007. At what distance do wolves move away from an approaching human? Canadian Journal of Zoology 85(11):1193-1197. http://dx.doi.org/10.1139/Z07-099

Kasworm, W. F., and T. L. Manley. 1990. Road and trail influences on grizzly bears and black bears in
Northwest Montana. Bears: Their Biology and Management 8:79-84. http://dx.doi.org/10.2307/38 $\underline{72905}$

Keating, K. A., and S. Cherry. 2004. Use and interpretation of logistic regression in habitatselection studies. Journal of Wildlife Management 68:774-789. http://dx.doi.org/10.2193/0022-541X(2004) 068[0774:UAIOLR]2.0.CO;2

Keller, B. J., and L. C. Bender. 2007 Bighorn sheep response to road-related disturbances in Rocky Mountain National Park, Colorado. Journal of Wildlife Management 71(7):2329-2337. http://dx.do i.org/10.2193/2006-486

Kortello, A. D., T. E. Hurd, and D. L. Murray. 2007. Interactions between cougars (Puma concolor) and gray wolves (Canis lupus) in Banff National Park, Alberta. Ecoscience 14(2):214-222. http://dx.doi.or g/10.2980/1195-6860(2007)14[214:IBCPCA]2.0.CO;2

Kuck, L., G. L. Hompland, and E. H. Merrill. 1985. Elk calf response to simulated mine disturbance. Journal of Wildlife Management 49(3):751-757. http://dx.doi.org/10.2307/3801706

Kunkel, K. E., and D. H. Pletscher. 2000. Habitat factors affecting vulnerability of moose to predation by wolves in southeastern British Columbia. Canadian Journal of Zoology 78(1):150-157. http:/ /dx.doi.org/10.1139/z99-181

Long, J. S., and J. Freese. 2006. Regression models for categorical dependent variables using Stata Second edition. Stata Press, College Station, Texas, USA.

Mao, J. S., M. S. Boyce, D. W. Smith, F. J. Singer, D. J. Vales, J. M. Vore, and E. H. Merrill. 2005. Habitat selection by elk before and after wolf reintroduction in Yellowstone National Park. Journal of Wildlife Management 69(4):1691-1707. http://dx.doi.org/10.2193/0022-541X(2005)69[1691: HSBEBA]2.0.CO;2

Margules, C. R., and R. L. Pressey. 2000. Systematic conservation planning. Nature 405:243-253. http://dx.doi.org/10.1038/35012251

Massolo, A., and A. Meriggi. 1998. Factors affecting habitat occupancy by wolves in northern Apennines (northern Italy): a model of habitat 
suitability. Ecography 21(2):97-107. http://dx.doi.o rg/10.1111/j.1600-0587.1998.tb00663.x

McDermid, G. J., S. E. Franklin, and E. F. LeDrew. 2005. Remote sensing for large-area habitat mapping. Progress in Physical Geography 29 (4):449-474. http://dx.doi.org/10.1191/0309133305 pp455ra

McNay, M. E. 2002. Wolf-human interactions in Alaska and Canada: a review of the case history. Wildlife Technical Bulletin 13. Alaska Department of Fish and Game, Juneau, Alaska, USA.

Mech, L. D., and L. E. Boitani. 2003. Wolves: behavior, ecology, and conservation. The University of Chicago Press, Chicago, Illinois, USA.

Miller, S. G., R. L. Knight, and C. K. Miller. 1998. Influence of recreational trails on breeding bird communities. Ecological Applications 8(1):162-169. http://dx.doi.org/10.1016/S1240-1307(98)80058-7

Moorcroft, P. R., and A. Barnett. 2008. Mechanistic home range models and resource selection analysis: a reconciliation and unification. Ecology 89 (4):1112-1119. http://dx.doi.org/10.1890/06-1985.1

Musiani, M., S. M. Anwar, G. J. McDermid, M. Hebblewhite, and D. J. Marceau. 2010. How humans shape wolf behavior in Banff and Kootenay National Parks, Canada. Ecological Modelling 221 (19):2374-2387. http://dx.doi.org/10.1016/j.ecolmo del.2010.06.019

Mysterud, A., and R. A. Ims. 1998. Functional responses in habitat use: availability influences relative use in trade-off situations. Ecology 79 (4):1435-1441. http://dx.doi.org/10.2307/176754

Nielsen, S. E., M. S. Boyce, G. B. Stenhouse, and R. H. M. Munro. 2002. Modeling grizzly bear habitats in the Yellowhead ecosystem of Alberta: taking autocorrelation seriously. Ursus 13:45-56.

Nielsen, S. E., S. Herrero, M. S. Boyce, R. D. Mace, B. Benn, M. L. Gibeau, and S. Jevons. 2004. Modelling the spatial distribution of human-caused grizzly bear mortalities in the central Rockies ecosystem of Canada. Biological Conservation 120 (1):101-113. http://dx.doi.org/10.1016/j.biocon.200 $\underline{4.02 .020}$
Oakleaf, J. K., D. L. Murray, J. R. Oakleaf, E. E. Bangs, C. M. Mack, D. W. Smith, J. A. Fontaine, M. D. Jimenez, T. J. Meier, and C. C. Niemeyer. 2006. Habitat selection by recolonizing wolves in the northern Rocky Mountains of the United States. Journal of Wildlife Management 70(2):554-563. http://dx.doi.org/10.2193/0022-541X(2006)70[554: HSBRWI]2.0.CO;2

Oxley, D. J., M. B. Fenton, and G. R. Carmody. 1974. The effects of roads on populations of small mammals. Journal of Applied Ecology 11(1):51-59. http://dx.doi.org/10.2307/2402004

Papouchis, C. M., F. J. Singer, and W. B. Sloan. 2001. Responses of desert bighorn sheep to increased human recreation. Journal of Wildlife Management 65(3):573-582. http://dx.doi.org/10.2 $\underline{307 / 3803110}$

Paquet, P. C., J. Wierchowski, and C. Callaghan. 1996. Effects of human activity on gray wolves wolves in the Bow River Valley, Banff National Park, Alberta. Chapter 7 in J. Green, C. Pacas, L. Cornwell, and S. Bayley, editors. Ecological outlooks project. A cumulative effects assessment and futures outlook for the Banff Bow Valley. Prepared for the Banff Bow Valley Study, Department of Canadian Heritage, Ottawa, Ontario, Canada.

Peters, R. L., and J. D. S. Darling. 1985. The greenhouse effect and nature reserves. BioScience 35(11):707-717. http://dx.doi.org/10.2307/1310052

Petorelli, N., J. O. Vik, A. Mysterud, J. M. Gaillard, C. J. Tucker, and N. C. Stenseth. 2005. Using the satellite-derived NDVI to assess ecological responses to environmental change. Trends in Ecology and Evolution 20(9):503-510. http://dx.do i.org/10.1016/j.tree.2005.05.011

Robinson, G. G., M. Hebblewhite, and E. H. Merrill. 2010. Are migrant and resident elk (Cervus elaphus) exposed to similar forage and predation risk on their sympatric winter range? Oecologia 163(1):265-275. http://dx.doi.org/10.1007/s00442-010-1620-6

Rost, G. R., and J. A. Bailey. 1979. Distribution of mule deer and elk in relation to roads. Journal of Wildlife Management 43(3):634-641. http://dx.doi. org/10.2307/3808741 
Rowland, M. M., M. J. Wisdom, B. K. Johnson, and J. G. Kie. 2000. Elk distribution and modeling in relation to roads. Journal of Wildlife Management 64(3):672-684. http://dx.doi.org/10.2307/3802737

Sawyer, H., R. M. Nielson, F. G. Lindzey, L. Keith, J. H. Powell, and A. A. Abraham. 2007. Habitat selection of Rocky Mountain elk in a nonforested environment. Journal of Wildlife Management 71 (3):868-874. http://dx.doi.org/10.2193/2006-131

Schultz, R. D., and J. A. Bailey. 1978. Responses of national park elk to human activity. Journal of Wildlife Management 42(1):91-100. http://dx.doi.o rg/10.2307/3800694

Shepherd, B., and J. Whittington. 2006. Response of wolves to corridor restoration and human use management. Ecology and Society 11(2): 1. [online] URL: http://www.ecologyandsociety.org/vol11/iss2/ $\underline{\operatorname{art} 1 /}$

Shively, K. J., A. W. Alldredge, and G. E. Phillips. 2005. Elk reproductive response to removal of calving season disturbance by humans. Journal of Wildlife Management 69(3):1073-1080. http://dx.do i.org/10.2193/0022-541X(2005)069[1073:ERRTRO] 2.0.CO;2

Stubblefield, C. H., K. T. Vierling, and M. A. Rumble. 2006. Landscape-scale attributes of elk centers of activity in the central Black Hills of South Dakota. Journal of Wildlife Management 70 (4):1060-1069. http://dx.doi.org/10.2193/0022-541X (2006)70[1060:LAOECO]2.0.CO;2

Taylor, A. R., and R. L. Knight. 2003. Wildlife responses to recreation and associated visitor perceptions. Ecological Applications 13(4):951-963. http://dx.doi.org/10.1890/1051-0761(2003)13[951: WRTRAA]2.0.CO;2

Theuerkauf, J., W. Jedrzejewski, K. Schmidt, and R. Gula. 2001. Impact of human activity on daily movement patterns of wolves(Canis lupus) in the Bialowieza Forest, Poland. Pages 206-208 in R. Field, R. J. Warren, H. Okarma, and P. R. Sievert, editors. Wildlife, land, and people: priorities for the 21st century: Proceedings of the Second International Wildlife Management Congress. The Wildlife Society, Bethesda, Maryland, USA.
Theuerkauf, J., W. Jedrzejewski, K. Schmidt, and R. Gula. 2003. Spatiotemporal segregation of wolves from humans in the Bialowieza Forest (Poland). Journal of Wildlife Management 67 (4):706-716. http://dx.doi.org/10.2307/3802677

Thurber, J. M., R. O. Peterson, T. D. Drummer, and S. A. Thomasma. 1994. Gray wolf response to refuge boundaries and roads in Alaska. Wildlife Society Bulletin 22:61-67.

Toweill, D. E., and J. W. E. Thomas. 2002. North American elk: ecology and management. Smithsonian Institute Press, Washington, D.C., USA.

Trombulak, S. C., and C. A. Frissell. 2000. Review of ecological effects of roads on terrestrial and aquatic communities. Conservation Biology 14 (1):18-30. http://dx.doi.org/10.1046/j.1523-1739.20 $\underline{00.99084 . X}$

Watson, A. E., D. N. Cole, D. L. Turner, and P. S. Reynolds. 2000. Wilderness recreation use estimation: a handbook of methods and systems. U. S. Forest Service, General Technical Report RMRSGTR-56. Rocky Mountain Research Station, Ogden, Utah, USA.

Weaver, J. L., P. C. Paquet, and L. F. Ruggiero. 1996. Resilience and conservation of large carnivores in the Rocky Mountains. Conservation Biology 10(4):964-976. http://dx.doi.org/10.1046/j. 1523-1739.1996.10040964.x

Whittington, J., C. C. St. Clair, and G. Mercer. 2004. Path tortuosity and the permeability of roads and trails to wolf movement. Ecology and Society 9(1): 4. [online] URL: http://www.ecologyandsociety.org/ vol9/iss1/art4/

Whittington, J., C. C. St. Clair, and G. Mercer. 2005. Spatial responses of wolves to roads and trails in mountain valleys. Ecological Applications 15 (2):543-553. http://dx.doi.org/10.1890/03-5317

Wilcove, D. S., D. Rothstein, J. Dubow, A. Phillips, and E. Losos. 1998. Quantifying threats to imperiled species in the United States. BioScience 48 (8):607-615. http://dx.doi.org/10.2307/1313420 
Wisdom, M. J., A. A. Ager, H. K. Preisler, N. J. Cimon, and B. K. Johnson. 2004. Effects of off-road recreation on mule deer and elk. Transactions of the 69th North American Wildlife and Natural Resource Conference. 531-550.

Witmer, G. W., and D. S. deCalesta. 1985. Effect of forest roads on habitat use by roosevelt elk. Northwest Science 59:122-125.

Yost, A. C., and R. G. Wright. 2001. Moose, caribou, and grizzly bear distribution in relation to road traffic in Denali National Park, Alaska. Arctic 54:41-48. 
APPENDIX 1. Model results. * = reference category.

Table A1.1. Model results for wolves and trails. Results predict wolf occurrence near trails using matched case-control logistic regression.

\begin{tabular}{lcccc}
\hline Variable & Coeff. & Robust SE & z & P-value \\
Cover & -0.084 & 0.036 & -2.29 & 0.022 \\
Elevation & -0.002 & $<0.001$ & -15.32 & $<0.001$ \\
Slope & -0.041 & 0.002 & -16.94 & $<0.001$ \\
Trail Activity & 0.001 & 0.003 & 0.38 & 0.705 \\
$0-50 \mathrm{~m}$ & 0.320 & 0.079 & 4.07 & $<0.001$ \\
$51-200 \mathrm{~m}$ & 0.233 & 0.062 & 3.75 & $<0.001$ \\
$201-400 \mathrm{~m}$ & 0.226 & 0.060 & 3.77 & $<0.001$ \\
$401-600 \mathrm{~m}$ & 0.017 & 0.061 & 0.28 & 0.779 \\
$601-800 \mathrm{~m}$ & 0.039 & 0.063 & 0.63 & 0.531 \\
$>800 \mathrm{~m}$ & $*$ & $*$ & $*$ & $*$ \\
$0-50 \mathrm{~m}$ Trail Activity & -0.129 & 0.062 & -2.08 & 0.037 \\
$51-200 \mathrm{~m}$ Trail Activity & -0.079 & 0.040 & -1.98 & 0.048 \\
$201-400 \mathrm{~m}$ *Trail Activity & -0.067 & 0.033 & -2.03 & 0.042 \\
$401-600 \mathrm{~m} *$ Trail Activity & 0.005 & 0.011 & 0.44 & 0.658 \\
$601-800 \mathrm{~m}$ *Trail Activity & 0.003 & 0.003 & 0.80 & 0.424 \\
$>800 \mathrm{~m}$ Trail Activity & $*$ & $*$ & $*$
\end{tabular}

Table A1.2. Model results for wolves near roads. Results predict wolf occurrence near roads using matched case-control logistic regression.

\begin{tabular}{lcccc}
\hline Variable & Coeff. & Robust SE & $\mathbf{z}$ & P-value \\
Cover & -0.091 & 0.042 & -2.18 & 0.029 \\
Elevation & -0.002 & $<0.001$ & -12.58 & $<0.001$ \\
Slope & -0.048 & 0.003 & -17.02 & $<0.001$ \\
Road Activity & 0.004 & $<0.001$ & 4.89 & $<0.001$ \\
$0-50 \mathrm{~m}$ & 0.279 & 0.144 & 1.94 & 0.052 \\
$51-200 \mathrm{~m}$ & 0.418 & 0.112 & 3.74 & $<0.001$ \\
\hline
\end{tabular}




\begin{tabular}{lcccc}
\hline $201-400 \mathrm{~m}$ & 0.355 & 0.107 & 3.31 & 0.001 \\
$401-600 \mathrm{~m}$ & 0.182 & 0.120 & 1.51 & 0.130 \\
$601-800 \mathrm{~m}$ & 0.060 & 0.143 & 0.42 & 0.677 \\
$>800 \mathrm{~m}$ & $*$ & $*$ & $*$ & $*$ \\
$0-50 \mathrm{~m} *$ Road Activity & -0.002 & 0.001 & -2.94 & 0.003 \\
$51-200 \mathrm{~m} *$ Road Activity & -0.001 & $<0.001$ & -1.96 & 0.049 \\
$201-400 \mathrm{~m} *$ Road Activity & $<0.001$ & $<0.001$ & -0.81 & 0.418 \\
$401-600 \mathrm{~m} *$ Road Activity & $<0.001$ & $<0.001$ & -0.32 & 0.747 \\
$601-800 \mathrm{~m} * \operatorname{Road}$ Activity & $<0.001$ & $<0.001$ & -0.50 & 0.617 \\
$>800 \mathrm{~m}$ Road Activity & $*$ & $*$ & $*$ & $*$
\end{tabular}

Table A1.3. Model results for elk near trails. Results predict elk occurrence near trails using matched case-control logistic regression.

\begin{tabular}{lcccc}
\hline Variable & Coeff. & Robust SE & z & P-value \\
Elevation & $<-0.001$ & $<0.001$ & -0.52 & 0.605 \\
Slope & -0.018 & 0.003 & -5.34 & $<0.001$ \\
Greenness & 0.168 & 0.023 & 7.35 & $<0.001$ \\
Trail Activity & 0.026 & 0.019 & 1.36 & 0.173 \\
$0-50 \mathrm{~m}$ & 0.229 & 0.391 & 0.59 & 0.558 \\
$51-200 \mathrm{~m}$ & -0.142 & 0.196 & -0.72 & 0.471 \\
$201-400 \mathrm{~m}$ & 0.027 & 0.121 & 0.22 & 0.822 \\
$401-600 \mathrm{~m}$ & 0.362 & 0.117 & 3.10 & 0.002 \\
$601-800 \mathrm{~m}$ & 0.324 & 0.113 & 2.86 & 0.004 \\
$>800 \mathrm{~m}$ & $*$ & $*$ & $*$ & $*$ \\
$0-50 \mathrm{~m} *$ Trail Activity & -0.350 & 0.277 & -1.26 & 0.206 \\
$51-200 \mathrm{~m} *$ Trail Activity & -0.091 & 0.050 & -1.78 & 0.075 \\
$201-400 \mathrm{~m} *$ Trail Activity & -0.071 & 0.030 & -2.37 & 0.018 \\
$401-600 \mathrm{~m} *$ Trail Activity & -0.028 & 0.029 & -0.98 & 0.329 \\
$601-800 \mathrm{~m} *$ Trail Activity & -0.033 & 0.016 & -2.03 & 0.042 \\
$>800 \mathrm{~m} *$ Trail Activity & $*$ & $*$ & $*$ \\
\hline
\end{tabular}


Table A1.4 . Model results for elk near roads. Results predict elk occurrence near roads using matched case-control logistic regression.

\begin{tabular}{lcccc}
\hline Variable & Coeff. & Robust SE & $\mathbf{z}$ & P-value \\
Elevation & -0.002 & $<0.001$ & -5.71 & $<0.001$ \\
Slope & 0.001 & 0.005 & 0.11 & 0.916 \\
Greenness & 0.211 & 0.026 & 8.11 & $<0.001$ \\
Road Activity & -0.001 & 0.001 & -1.80 & 0.071 \\
$0-50 \mathrm{~m}$ & 0.103 & 0.219 & 0.47 & 0.637 \\
$51-200 \mathrm{~m}$ & 0.017 & 0.138 & 0.12 & 0.903 \\
$201-400 \mathrm{~m}$ & 0.153 & 0.126 & 1.22 & 0.223 \\
$401-600 \mathrm{~m}$ & 0.100 & 0.118 & 0.84 & 0.400 \\
$601-800 \mathrm{~m}$ & 0.228 & 0.106 & 2.16 & 0.031 \\
$>800 \mathrm{~m}$ & $*$ & $*$ & $*$ & $*$ \\
$0-50 \mathrm{~m} * \operatorname{Road}$ Activity & -0.006 & 0.002 & -2.53 & 0.011 \\
$51-200 \mathrm{~m} * \operatorname{Road}$ Activity & -0.001 & 0.001 & 1.26 & 0.208 \\
$201-400 \mathrm{~m} * \operatorname{Road}$ Activity & $<-0.001$ & 0.001 & -0.02 & 0.988 \\
$401-600 \mathrm{~m} * \operatorname{Road}$ Activity & $<0.001$ & 0.001 & 0.16 & 0.870 \\
$601-800 \mathrm{~m} * \operatorname{Road}$ Activity & $<-0.001$ & 0.001 & -0.28 & 0.779 \\
$>800 \mathrm{~m}$ Road Activity & $*$ & $*$ & $*$
\end{tabular}

Table A1.5. Model results for wolves on trails. Results predict wolf occurrence near trails using matched case-control logistic regression and $0-50 \mathrm{~m}$ as the reference category.

\begin{tabular}{lcccc}
\hline Variable & Coeff. & Robust SE & $\mathbf{z}$ & P-value \\
Cover & -0.084 & 0.036 & -2.29 & 0.022 \\
Elevation & -0.002 & $<0.001$ & -15.32 & $<0.001$ \\
Slope & -0.041 & 0.002 & -16.94 & $<0.001$ \\
Trail Activity & -0.127 & 0.061 & -2.06 & 0.039 \\
$0-50 \mathrm{~m}$ & $*$ & $*$ & $*$ & $*$ \\
$51-200 \mathrm{~m}$ & -0.086 & 0.066 & -1.31 & 0.192 \\
\hline
\end{tabular}




\begin{tabular}{lcccc}
\hline $201-400 \mathrm{~m}$ & -0.094 & 0.073 & -1.29 & 0.198 \\
$401-600 \mathrm{~m}$ & -0.302 & 0.081 & -3.76 & $<0.001$ \\
$601-800 \mathrm{~m}$ & -0.281 & 0.086 & -3.25 & 0.001 \\
$>800 \mathrm{~m}$ & -0.320 & 0.079 & -4.07 & $<0.001$ \\
$0-50 \mathrm{~m} *$ Trail Activity & $*$ & $*$ & $*$ & $*$ \\
$51-200 \mathrm{~m} *$ Trail Activity & 0.049 & 0.063 & 0.78 & 0.433 \\
$201-400 \mathrm{~m} *$ Trail Activity & 0.061 & 0.066 & 0.93 & 0.355 \\
$401-600 \mathrm{~m} *$ Trail Activity & 0.134 & 0.063 & 2.13 & 0.034 \\
$601-800 \mathrm{~m} *$ Trail Activity & 0.131 & 0.062 & 2.12 & 0.034 \\
$>800 \mathrm{~m} *$ Trail Activity & 0.129 & 0.062 & 2.08 & 0.037 \\
& & & & \\
\hline
\end{tabular}

